\title{
Weighing the evidence for pharmacological treatment interventions in mild COPD; a narrative perspective
}

\author{
Dave Singh ${ }^{1 *}$, Anthony D. D'Urzo ${ }^{2}$, James F. Donohue ${ }^{3}$ and Edward M. Kerwin ${ }^{4}$
}

\begin{abstract}
There is increasing focus on understanding the nature of chronic obstructive pulmonary disease (COPD) during the earlier stages. Mild COPD (Global Initiative for Chronic Obstructive Lung Disease [GOLD] stage 1 or the nowwithdrawn GOLD stage 0) represents an early stage of COPD that may progress to more severe disease. This review summarises the disease burden of patients with mild COPD and discusses the evidence for treatment intervention in this subgroup.

Overall, patients with mild COPD suffer a substantial disease burden that includes persistent or potentially debilitating symptoms, increased risk of exacerbations, increased healthcare utilisation, reduced exercise tolerance and physical activity, and a higher rate of lung function decline versus controls. However, the evidence for treatment efficacy in these patients is limited due to their frequent exclusion from clinical trials. Careful assessment of disease burden and the rate of disease progression in individual patients, rather than a reliance on spirometry data, may identify patients who could benefit from earlier treatment intervention.
\end{abstract}

Keywords: Chronic obstructive pulmonary disease, Corticosteroid, Early intervention

\section{Background}

Chronic obstructive pulmonary disease (COPD) is characterised by airflow obstruction that arises in response to exposure to noxious particles, commonly from cigarette smoking [1]. The current Global Initiative for Chronic Obstructive Lung Disease (GOLD) report recommends that following a spirometrically confirmed diagnosis of airflow limitation, an assessment based on a combination of exacerbation risk and symptom criteria is performed to evaluate severity and guide treatment decisions [1]. However, many patients remain undiagnosed until the more advanced stages of the disease [2,3]. COPD is a heterogeneous condition, with a high degree of variation in the clinical presentation and rate of disease progression between individuals [4-6], and it has been suggested that greater emphasis should be placed on diagnosis and treatment earlier in the course of the disease to potentially slow progression $[3,7,8]$.

\footnotetext{
* Correspondence: dsingh@meu.org.uk

${ }^{1}$ University of Manchester, Medicines Evaluation Unit, Manchester University NHS Foundation Trust, Manchester M23 9QZ, UK

Full list of author information is available at the end of the article
}

Mild airflow limitation is defined by GOLD criteria as a post-bronchodilator forced expiratory volume in $1 \mathrm{~s}$ $\left[\mathrm{FEV}_{1}\right] /$ forced vital capacity $[\mathrm{FVC}]$ ratio $<0.7$ and a postbronchodilator $\mathrm{FEV}_{1} \geq 80 \%$ predicted (GOLD stage 1) [1]. The mean reported prevalence of GOLD stage 1 COPD ranges from 2.5\% (European Community Respiratory Health Survey of adults aged 20-44 years in high-income countries) [9] to 8.1\% (BOLD Study of adults aged $\geq 40)[10,11]$. Patients with GOLD stage 1 COPD frequently receive limited or no treatment [2]; however, these patients often suffer significant morbidity, including respiratory symptoms, exacerbations, limitation of exercise capacity and reduced physical activity $[12,13]$. Some clinical trials suggest that patients with mild COPD may benefit from treatment intervention [14-16], but evidence is limited as most randomised controlled trials of the commonly used inhaled treatments have not enrolled patients with mild COPD [16, 17].

According to the classical Fletcher-Peto model [18], $\mathrm{FEV}_{1}$ decreases gradually over a lifetime in susceptible smokers, causing COPD. However, the rate of lung function decline in COPD is highly variable, being negatively 
affected by smoking and exacerbations, but also remaining relatively stable for long periods of time in many patients [5]. Furthermore, poor lung growth in early life - leading to low maximally attained $\mathrm{FEV}_{1}$ in early adulthood - also contributes to the development of COPD [4] and may lead to a COPD phenotype where airflow obstruction arises mainly due to poor lung growth. While some individuals with abnormal lung growth may suffer from accelerated lung function decline characteristic of COPD $[18,19]$ and go on to develop severe disease over time, other patients demonstrate a rate of lung function decline in later life that is lower compared with individuals who attained maximum lung growth [4]. Mild COPD therefore comprises a broad group of patients who have different disease trajectories, including many who have COPD mainly because of poor lung growth.

Early COPD has been defined broadly as 'an interval in time at the beginning of the disease course' [20]. A more precise operational definition of early COPD has recently been proposed for younger current or former smokers to identify individuals at high risk of rapid disease progression: patients aged $<50$ years with $\geq 10$ packyears smoking history and one or more of the following: 1) post-bronchodilator $\mathrm{FEV}_{1} / \mathrm{FVC}<$ lower limit of normal; 2) compatible computed tomography (CT) abnormalities (visual emphysema, air trapping, or bronchial thickening graded mild or worse); 3 ) evidence of accelerated $\mathrm{FEV}_{1}$ decline $(\geq 60 \mathrm{~mL} /$ year) that is accelerated relative to FVC [21]. It is important to recognise that 'early' and 'mild' COPD are different definitions, with the former focused on age of onset and the latter focused on pulmonary function [20]. Due to the challenges involved in the diagnosis of early COPD [20], there are currently few studies describing the clinical characteristics of this subgroup. The RETHINC study, which is currently ongoing, is a 12-week, Phase 3 study of the LABA/LAMA combination indacaterol/glycopyrrolate in symptomatic current and former smokers with normal $\mathrm{FEV}_{1}$ and may provide valuable insight into pharmacological intervention in patients with early COPD [22].

Mild COPD represents a group of patients who can practically be identified in clinical practice [11]. Mild COPD may progress to more severe and life-limiting disease over time in some individuals [11], although this progressive decline does not occur in all patients [20]. This has led to some doubts as to whether pharmacological treatment is required or if it would be effective in this group. Identification of patients with mild COPD with a greater disease burden and/or increased likelihood of disease progression may determine the most appropriate individuals for pharmacological interventions. Here, we provide a narrative review of the evidence concerning disease burden and progression in mild COPD.
We also review the limited evidence to support pharmacological treatment intervention in this patient population. Given the sparse nature of clinical trial evidence to support pharmacological treatment interventions in mild COPD, we debate the optimum treatment approaches in this group.

\section{Search strategy}

To evaluate different aspects of disease burden in mild COPD, we conducted PubMed searches for the terms 'early COPD', 'mild COPD', 'GOLD stage 0, 'GOLD stage 1, 'emphysema AND normal lung function' AND one of the following terms: 'symptoms/dyspnoea/dyspnea/ breathlessness/shortness of breath/chest tightness/ cough/sputum/phlegm/wheeze'; 'exacerbations'; 'physical activity/exercise' OR 'FEV/FEV 1 /lung function decline/ progression'. Descriptive reviews; commentaries; protocols; studies in a non-COPD therapy area (e.g. lung cancer, pulmonary hypertension, sleep apnoea); biomarker and genetic studies; diagnostic, methodological, prevalence/demographic, preference/adherence or comorbidity studies; studies not specifically in a mild COPD population/sub-population and studies without an informative comparator group were excluded unless of particular relevance.

\section{Disease burden in mild COPD \\ Symptom burden and health status}

Respiratory symptoms associated with COPD, including breathlessness, cough, sputum and wheeze, have a profound impact on patients' quality of life and overall health status [23-25]. Symptoms and their associated effects can precede the development of airflow limitation, as demonstrated in the SPIROMICS cohort [12], where respiratory symptoms were present in approximately $50 \%$ of current or former smokers with preserved $\mathrm{FEV}_{1} /$ FVC ratio $\geq 0.7$. The presence of respiratory symptoms in these subjects was associated with a higher rate of exacerbations and greater physical activity limitation versus asymptomatic subjects. It has also been reported that visual CT abnormalities were associated with higher COPD Assessment Test (CAT) scores in current or former smokers with normal lung function [26]. The importance of symptoms is illustrated by a study of patients with mild to moderate COPD (mean $\mathrm{FEV}_{1}$ $82.1 \%$ predicted); individuals with a CAT symptom score $\geq 10$ had significantly greater work productivity loss than patients without COPD [27].

The literature search highlighted studies that assessed symptom burden specifically in patients with mild COPD (Table 1). In particular, the COPDGene study reported worse patient-reported outcomes and worse quality of life for mild COPD compared with controls; modified Medical Research Council (mMRC) score odds 
Table 1 Studies reporting symptom burden, health status, exacerbations and HCRU in patients with mild COPD

\begin{tabular}{|c|c|c|c|}
\hline Study & Population & Relevant outcome measure(s) & $\begin{array}{l}\text { Finding in mild COPD versus } \\
\text { controls }\end{array}$ \\
\hline \multicolumn{4}{|c|}{ Symptom burden and health status studies } \\
\hline Vaz Fragoso et al. 2016 [28] & $\begin{array}{l}\text { Smokers with/without COPD } \\
\text { (COPDGene cohort) }\end{array}$ & $\mathrm{mMRC}, \mathrm{SGRQ}$ & Worse dyspnoea and HRQoL \\
\hline Bridevaux et al. 2008 [29] & $\begin{array}{l}\text { Never smokers or current and former } \\
\text { smokers with COPD (SAPALDIA } \\
\text { cohort) }\end{array}$ & SF-36 & Worse HRQoL \\
\hline \multicolumn{4}{|c|}{ Exacerbations and HCRU outcomes } \\
\hline Dransfield et al. 2017 [30] & $\begin{array}{l}\text { Smokers with/without COPD } \\
\text { (COPDGene cohort) }\end{array}$ & Exacerbations, FEV 1 decline & $\begin{array}{l}\text { Exacerbations in mild COPD } \\
\text { associated with greater } \mathrm{FEV}_{1} \text { loss } \\
\text { versus GOLD 0/2/3/4; exacerbation } \\
\text { rate was similar for mild COPD } \\
\text { versus GOLD } 0 \text { controls }\end{array}$ \\
\hline Lee et al. 2016 [31] & COPD & Exacerbations & $\begin{array}{l}\text { Lower exacerbation rate in mild } \\
\text { COPD }^{\mathrm{b}}(0.4) \text { versus GOLD } 3 / 4(0.9)\end{array}$ \\
\hline $\begin{array}{l}\text { Garcia-Aymerich et al. } \\
2011 \text { [32] }\end{array}$ & $\begin{array}{l}\text { Participants from CHS and ARIC } \\
\text { cohorts with/without COPD }\end{array}$ & Hospitalisations due to COPD & $\begin{array}{l}\text { Increased hospitalisation risk in mild } \\
\text { COPD (adjusted IRR } 2.1 \text { and 3.2) } \\
\text { versus controls }\end{array}$ \\
\hline de Marco et al. 2004 [9] & $\begin{array}{l}\text { Younger adults ( } 20-44 \text { years) from } \\
\text { the ECRHS cohort with/without } \\
\text { COPD }\end{array}$ & Patient-reported HCRU ${ }^{c}$ & $\begin{array}{l}\text { Greater HCRU in participants with } \\
\text { COPD (all stages including stage 0) } \\
\text { versus controls }\end{array}$ \\
\hline
\end{tabular}

Of the results identified by the search terms stated, only relevant, original studies including a mild or undiagnosed COPD population are shown. ARIC: Atherosclerosis Risk in Communities; CHS: Cardiovascular Health Study; COPD: chronic obstructive pulmonary disease; ECRHS: European Community Respiratory Health Survey; FEV 1 : forced expiratory volume in 1 s; GOLD: Global Initiative for Chronic Obstructive Lung Disease; HCRU: healthcare resource utilisation; HLQ: health and labour questionnaire; HRQoL: health-related quality of life; IRR: incidence rate ratio; mMRC: modified Medical Research Council Dyspnea Scale; SF-36: 36-item Short-Form Survey; SGRQ: St George's Respiratory Questionnaire; SAPALDIA: Swiss Study on Air Pollution and Lung Diseases in Adults. ${ }^{a}$ mild COPD defined as GOLD 0 and/or 1 COPD, unless otherwise stated. ${ }^{b}$ mild COPD defined as GOLD stage 1 and 2 . ${ }^{c}$ including medication use, doctor visits and hospitalisations due to COPD

ratio 1.31, 95\% confidence interval (CI) 1.10-1.56; St George's Respiratory Questionnaire (SGRQ) score odds ratio 1.49 , 95\% CI 1.28-1.75 [28].

Primary care screening programmes have identified a high symptom burden in newly diagnosed patients with mild and moderate COPD [33, 34]. This illustrates the existence of a population, including patients with mild COPD, who suffer from potentially debilitating respiratory symptoms prior to receiving a diagnosis and gaining access to treatment.

\section{Exacerbations}

The rate of COPD exacerbations is related primarily to the history of previous exacerbations, but also to the severity of airflow limitation $[35,36]$. However, Woodruff et al. [12] reported an increased rate of exacerbations in symptomatic current or former smokers (0.27, standard deviation [SD] \pm 0.67$)$ compared with asymptomatic current or former smokers $(0.08, \mathrm{SD} \pm 0.31)$ or neversmokers (0.03, SD $\pm 0.21 ; p<0.001$ for both comparisons), suggesting a subpopulation with increased exacerbation risk in the early stages of COPD.

Of the studies we identified (Table 1), two reported that exacerbation risk is relatively low in mild COPD and increases with the degree of airflow limitation [31, 32]. However, studies that compared GOLD stage $0 / 1$ patients with control subjects with normal lung function $[9,32]$ found a significantly higher rate of exacerbations or healthcare utilisation in the GOLD stage 0/1 patients (adjusted incidence rate ratios 2.1 and 3.2, respectively; by comparison, 8.0 and 25.5 for GOLD 2, and GOLD 3 or 4, respectively [32]). It has also been reported that the association between exacerbation rate and $\mathrm{FEV}_{1}$ decline was stronger for patients in GOLD stage 1 than for patients in any other stage [30]. This suggests that the effect of exacerbations on $\mathrm{FEV}_{1}$ decline may be particularly harmful in the earlier stages of COPD.

\section{Exercise tolerance and physical activity}

The term 'physical activity' refers to the daily level of physical activity (such as time spent walking or exercising), and is dependent on numerous factors including physiological, behavioural, social and environmental influences. In contrast, 'exercise tolerance' (also referred to as exercise performance or capacity) is the amount of exercise an individual is capable of, and is often assessed using laboratory exercise tests such as the 6-min walk test $[37,38]$. In patients with COPD, impaired lung function and respiratory symptoms (especially dyspnoea) lead to reduced physical activity and decreased exercise tolerance [37]. Patients avoid exertional dyspnoea by becoming less active, and the resultant deconditioning aggravates the symptom [39]. Thus, COPD leads to a significant reduction in patients' activity levels, which 
worsens with increasing severity [39-41]. Maintaining regular physical activity reduces rates of hospitalisation and both all-cause and respiratory-related mortality in patients with COPD [42]; therefore, disrupting the downward spiral of inactivity at any stage of COPD may have substantial therapeutic value.

Our literature search identified many studies reporting reduced exercise tolerance in patients with mild COPD (Table 2), often using cycle testing [28, 41, 44, 47, 48, 51]. A common reason for this phenomenon is dynamic lung hyperinflation, which leads to impaired ventilation and dyspnoea [54]. The studies (see Additional file 1: Table S1) also show that ventilatory inefficiency $[43,48$, $49]$ and diminished oxygen transport $[47,50,52]$ occur even in patients with mild airflow limitation. Studies measuring physical activity in mild COPD have been less common; however, Watz et al reported no significant difference in mean steps per day and a higher proportion of patients who were predominantly sedentary when comparing patients with mild COPD with controls [41]. Patients with GOLD stages 2,3 and 4 had significantly lower mean steps per day compared with controls and ranged from predominantly sedentary (GOLD stage 2) to very inactive (GOLD stages 3 and 4) [41]. Overall, these studies demonstrate a reduction in physical activity and exercise capacity in mild COPD associated with abnormalities of gas exchange.

Table 2 Studies reporting physical activity and exercise capacity in patients with mild COPD

\begin{tabular}{|c|c|c|c|}
\hline Study & Population & Relevant outcome measure(s) & Finding \\
\hline Jones et al. 2017 [43] & $\begin{array}{l}\text { Mild to moderate COPD } \\
\text { (post-bronchodilator FEV } 1 \geq 60 \% \\
\text { predicted); controls without COPD }\end{array}$ & Incremental exercise test & $\begin{array}{l}\text { Increased dyspnoea and ventilatory } \\
\text { inefficiency in mild-to-moderate } \\
\text { COPD versus controls }\end{array}$ \\
\hline Caram et al. 2016 [44] & $\begin{array}{l}\text { Never smokers; smokers with/ } \\
\text { without mild-to-moderate COPD } \\
\text { (post-bronchodilator FEV } \text { F }_{1}>50 \% \\
\text { predicted) }\end{array}$ & $6 \mathrm{MWT}$ & $\begin{array}{l}\text { Lower exercise capacity in mild-to- } \\
\text { moderate COPD versus never } \\
\text { smokers }\end{array}$ \\
\hline Vaz Fragoso et al. 2016 [28] & $\begin{array}{l}\text { Smokers with/without COPD } \\
\text { (COPDGene cohort }[45,46])\end{array}$ & $6 \mathrm{MWT}$ & $\begin{array}{l}\text { Lower exercise capacity in mild } \\
\text { COPD versus controls } \\
\text { (non-significant) }\end{array}$ \\
\hline Elbehairy et al. 2015 [47] & Mild COPD; non-smoker controls & Symptom-limited cycle test & $\begin{array}{l}\text { Gas exchange abnormalities with } \\
\text { increased dyspnoea and exercise } \\
\text { intolerance in mild COPD versus } \\
\text { controls }\end{array}$ \\
\hline Neder et al. 2015 [48] & COPD; controls without COPD & Symptom-limited cycle test & $\begin{array}{l}\text { Increased ventilatory inefficiency and } \\
\text { reduced exercise capacity in mild } \\
\text { COPD versus controls }\end{array}$ \\
\hline Guenette et al. 2014 [49] & Mild COPD; controls without COPD & Symptom-limited cycle test & $\begin{array}{l}\text { Increased ventilatory requirements } \\
\text { and respiratory effort during exercise } \\
\text { in mild COPD versus controls }\end{array}$ \\
\hline Chin et al. 2013 [50] & Mild COPD; controls without COPD & Symptom-limited cycle test & $\begin{array}{l}\text { Reduced peak } \mathrm{O}_{2} \text { uptake; no peak } \\
\text { end-inspiratory lung volume increase } \\
\text { in mild COPD versus controls }\end{array}$ \\
\hline Díaz et al. 2013 [51] & $\begin{array}{l}\text { Dyspnoeic (mMRC score } \geq 1 \text { ) and } \\
\text { non-dyspnoeic patients with mild } \\
\text { COPD; smoker controls }\end{array}$ & Borg dyspnoea rating, $6 \mathrm{MWT}$ & $\begin{array}{l}\text { Decreased inspiratory capacity and } \\
\text { increased ventilatory demand during } \\
\text { exercise and reduced exercise } \\
\text { capacity in dyspnoeic COPD versus } \\
\text { non-dyspnoeic COPD or controls }\end{array}$ \\
\hline Watz et al. 2009 [41] & $\begin{array}{l}\text { COPD; controls with chronic } \\
\text { bronchitis }\end{array}$ & $\begin{array}{l}\text { Steps/day, minutes of at least } \\
\text { moderate activity, } 6 \mathrm{MWT}\end{array}$ & $\begin{array}{l}\text { Higher proportion of sedentary } \\
\text { patients in mild COPD versus chronic } \\
\text { bronchitis }\end{array}$ \\
\hline Ofir et al. 2008 [52] & $\begin{array}{l}\text { Symptomatic current or former } \\
\text { smokers with mild COPD; age- and } \\
\text { sex-matched former or non-smoker } \\
\text { controls }\end{array}$ & $\begin{array}{l}\text { Symptom-limited cycle test, Borg } \\
\text { dyspnoea rating }\end{array}$ & $\begin{array}{l}\text { Increased ventilatory requirements } \\
\text { and exertional dyspnoea, decreased } \\
\text { peak } \mathrm{O}_{2} \text { uptake in mild COPD versus } \\
\text { controls }\end{array}$ \\
\hline Carter et al. 1993 [53] & $\begin{array}{l}\mathrm{COPD}\left(\mathrm{FEV} / / \mathrm{FVC}, 0.6-0.7 ; \mathrm{FEV}_{1} \geq 60 \%\right. \\
\text { predicted); controls without COPD }\end{array}$ & $\begin{array}{l}\text { Resting and peak exercise gas } \\
\text { exchange (with symptom-limited } \\
\text { cycle test) }\end{array}$ & $\begin{array}{l}\text { Decreased maximal oxygen } \\
\text { consumption and ventilation, } \\
\text { reduced work capacity and maximal } \\
\text { heart rate in COPD versus controls }\end{array}$ \\
\hline
\end{tabular}

A total of 59 results were identified by the search terms stated; only relevant, original studies including a mild or undiagnosed COPD population are shown.

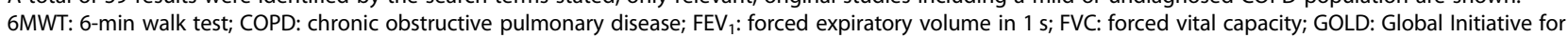

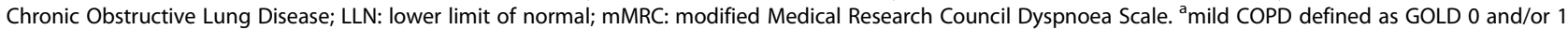
COPD, unless otherwise stated 


\section{Lung function decline and disease progression}

Accelerated decline of lung function is a characteristic feature of COPD [18]; however, since COPD results from a complex interaction between genetic factors [55] and the environment (smoking, exposure to dust/gases, burning of solid fuels/biomass, socioeconomic status) and is heterogeneous in nature $[1,56]$, it is perhaps no surprise that the progression of the disease is also heterogeneous, with rates of decline reported to vary widely both between individuals and between studies [4-6]. In addition, it has been suggested that $\mathrm{FEV}_{1}$ decline is inversely correlated with GOLD severity stage, with more rapid decline reported in patients with mild and moderate COPD than in those with severe/very severe COPD [5, 30, 57].

The literature search identified several papers reporting data for disease progression in patients with mild COPD or smokers with abnormal lung function (Fig. 1) [29, 58-60]. There is evidence that patients with mild COPD have an accelerated $\mathrm{FEV}_{1}$ decline compared with controls without COPD (Fig. 1) [29, 58]) and GOLD stages 2-4 [29], which is more prominent in patients with greater symptoms $[29,59]$. In contrast, one study reported that male heavy smokers with $\mathrm{FEV}_{1} / \mathrm{FVC}>0.7$ had a more rapid rate of decline irrespective of whether they were above or below the lower limit of normal (LLN), compared with individuals with $\mathrm{FEV}_{1} / \mathrm{FVC}<0.7$ and < LLN, (Fig. 1) [60].

\section{Mortality}

Our searches identified two studies that evaluated mortality risk in patients with mild COPD (Fig. 2) [61-63]. An analysis of all-cause mortality over 22 years in participants aged 27-74 from the First National Health and Nutrition Examination Survey follow-up cohort reported an increase in mortality risk in GOLD stage 1 (hazard ratio $[\mathrm{HR}]$ 1.2) compared with patients with no lung disease (HRs of 1.6 and 2.7 were calculated for GOLD stages 2 and 3, respectively) [62]. An analysis of all-cause mortality over 26 years in an occupational cohort of men aged 40-59 years (adjusting for patients who had never smoked) reported an increased mortality risk in GOLD stage 1 (HR 1.30) and symptomatic GOLD stage 0 (HR 1.35) compared with controls (HRs of 1.79 and 2.11 were calculated for GOLD stages 2 and 3, respectively) [61]. Additionally, in an analysis of all-cause mortality over 12.5 years in smokers aged $35-60$ years with mild and moderate COPD, it was reported that the presence of cough and phlegm symptoms together was associated with increased mortality risk (HR 1.27); dyspnoea was also associated with higher mortality risk (HR 1.16) compared with no cough and phlegm symptoms [63]. Of note, a large proportion of deaths in patients with mild COPD have been found to be the result of cardiovascular complications [14, 64], with deaths due to respiratory disease becoming increasingly common as the severity of COPD increased [65]. This suggests that screening for cardiovascular comorbidities and/or preventative treatment intervention in patients with mild COPD may be of benefit.

\section{Effective interventions in mild COPD}

In all patients with COPD, the elimination of risk factors through non-pharmacological interventions, such as smoking cessation, education, physical activity and (in some cases) pulmonary rehabilitation, forms an important component of the management strategy [1]. The GOLD report provides recommendations for pharmacotherapy and escalation/de-escalation strategies [1] based mainly on evidence from randomised controlled trials; however, the majority of such clinical trials have not included patients with mild COPD, so the evidence base for such recommendations in this population is less clear. Despite this, in the CanCOLD cohort of 5176 patients in primary care, $25 \%$ of patients diagnosed with mild COPD reported being prescribed pharmacological treatment for their COPD [66].

Our literature searches identified a range of interventional studies that assessed treatment effects in patients with mild COPD (pharmacological and non-pharmacological interventions summarised in Table 3 and Additional file 1: Table S1, respectively). However, it is important to note that the studies differed in the level of airflow limitation considered 'mild'.

The efficacy of various pharmacological interventions in large trials where patients with mild COPD have been included has been reported, but often the number of patients in the mild COPD subgroup is limited (Table 3). While inhaled corticosteroid (ICS) treatment is effective in reducing exacerbations in moderate to severe COPD, the existing evidence in mild COPD is not sufficient to recommend ICS in these patients $[68,69]$. Other studies investigating the effects of maintenance treatments including ICS and short-acting bronchodilators on lung function in patients with mild and moderate COPD have not shown any treatment effect [73, 74]. In contrast, a recent study reported a positive effect of tiotropium in reducing post-bronchodilator $\mathrm{FEV}_{1}$ decline between 0 and 24 months in patients with mild and moderate COPD, despite failing to meet its primary endpoint of reduced pre-bronchodilator $\mathrm{FEV}_{1}$ decline [72]. It should be noted, however, that no sub-analysis of mild COPD was presented in these studies, so the treatment effect in this group of interest is unclear. When studying patients with moderate COPD, tiotropium has been shown to improve lung function and patient-reported outcomes in patients who were naïve to maintenance therapy, suggesting benefits in initiating maintenance therapy early 


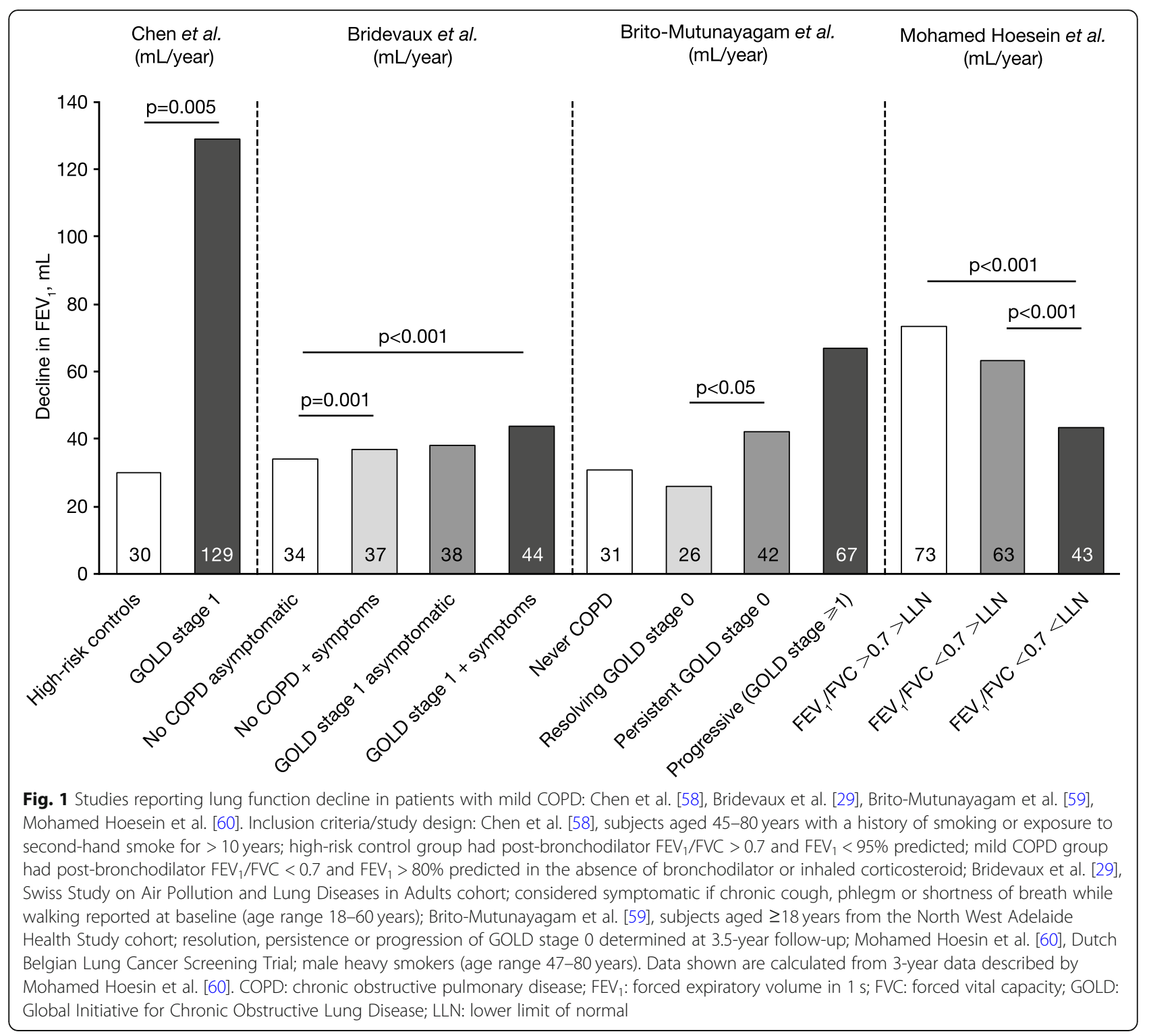

[75]; similar studies in mild COPD would be clinically informative. Studies specifically focused on mild COPD have not demonstrated any effect of either the oral antioxidant $\mathrm{N}$-acetylcysteine or a short-acting muscarinic antagonist/short-acting $\beta_{2}$-agonist combination on exercise tolerance $[70,71]$.

\section{Pharmacological intervention is warranted in mild COPD}

Several studies have demonstrated a substantial disease burden in mild COPD compared with controls [9, 28-34]. Furthermore, there is extensive evidence of reduced physical activity and exercise capacity in mild COPD that is associated with abnormalities of gas exchange [28, 43, 47$49,52,53]$. These findings demonstrate the presence of pathophysiological abnormalities in mild COPD associated with clinical consequences, and support the case to provide adequate bronchodilator treatment in these patients.

The examination of lung surgical specimens shows small airway destruction in mild COPD [76]. A recent study, also using surgical specimens, reported a decrease in the number of bronchioles in patients with GOLD stage 1 and GOLD stage 2 compared with control smokers, with a $40 \%$ reduction $(p=0.014)$ and a $43 \%$ reduction $(p=0.036)$ in the number of terminal bronchioles, respectively [77]. The remaining small airways showed features of narrowing and obstruction, while there was also a loss of alveolar surface area, with a $33 \%$ loss $(p=$ $0.019)$ and a $45 \%$ loss $(p=0.002)$ in patients with GOLD stage 1 and GOLD stage 2 , respectively [77]. These studies demonstrate the presence of significant pathology in mild COPD, particularly in the small airways. 


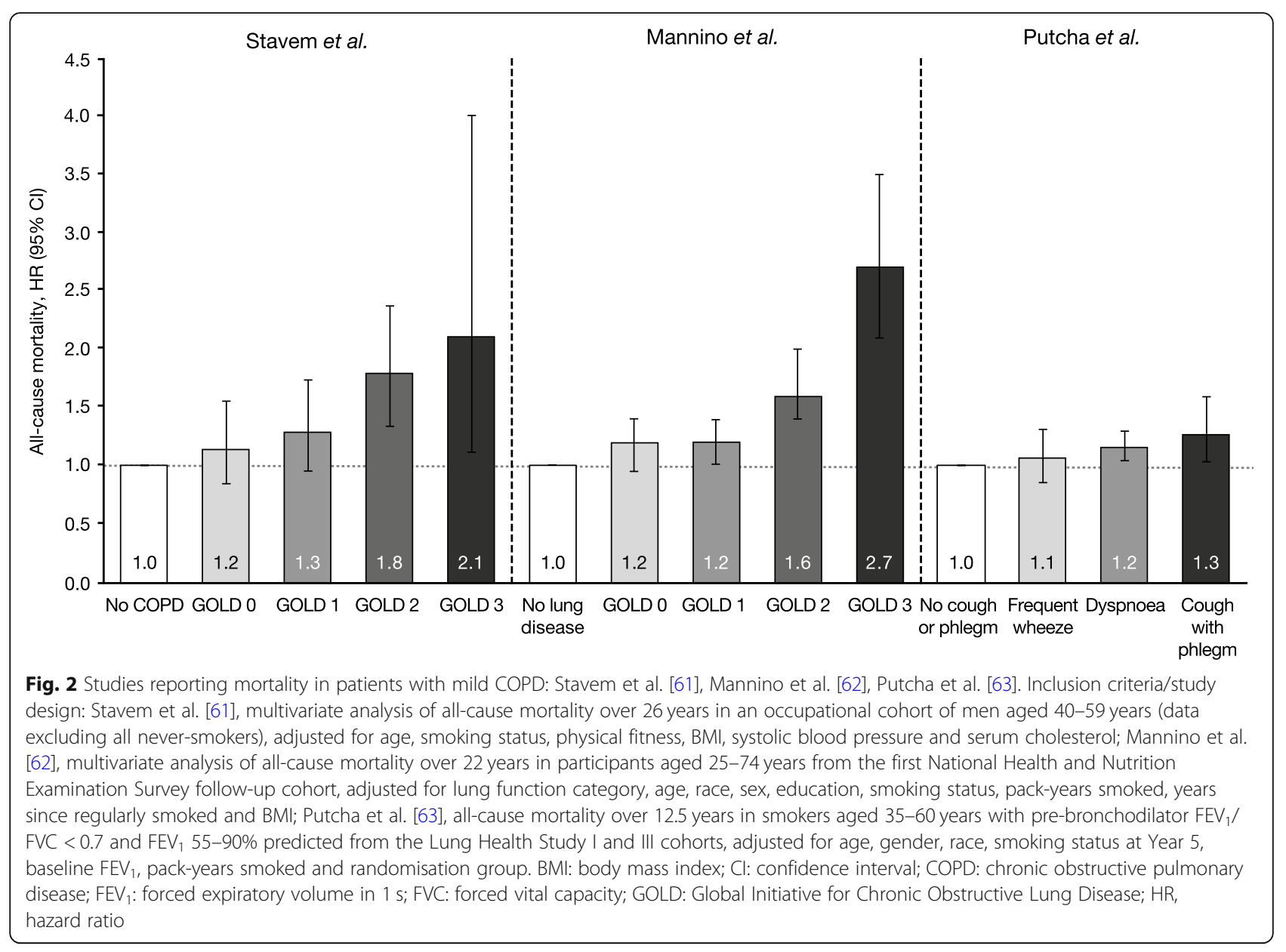

The importance of small airway disease in mild COPD has been confirmed by CT scanning using parametric response mapping in the COPDGene cohort $(n=1508)$; small airway disease was the main cause of gas trapping in mild to moderate COPD, with emphysema becoming more important in severe and very severe COPD [78]. Furthermore, $81 \%$ of patients with GOLD stage 1 and $42 \%$ of patients with GOLD stage 0 had evidence of emphysema or functional small airways disease through CT scanning [79]. Functional small airways disease was also associated with $\mathrm{FEV}_{1}$ decline in patients with GOLD stage 0 [78]. Overall, the evidence from these pathology and imaging studies demonstrates the presence of significant small airway disease in mild COPD, with progression to emphysema being a process that occurs subsequent to small airway remodelling and destruction. These mechanistic insights highlight the potential to target airway disease in mild COPD.

While exacerbations are more common in patients with moderate to severe COPD, there is evidence that some patients with mild COPD also suffer from these events. Exacerbations are associated with a greater $\mathrm{FEV}_{1}$ decline [80], and there is evidence that they have the greatest impact on $\mathrm{FEV}_{1}$ decline in mild COPD [30]. While the rate of exacerbations is higher in moderate to severe COPD, it appears that they are also important events in mild COPD. Research into the causes and prevention of exacerbations in mild COPD is sparse, but would be valuable given the impact of these events. Abnormal mucin production has been observed in patients with COPD and smokers without airflow limitation [81]; novel approaches to the treatment of mild COPD in the future might target mucins and their role in exacerbations.

The GOLD report recommends that antibiotics can be used to treat exacerbations in patients with COPD, guided by sputum purulence $[1,56]$; however, there has been little research on using antibiotics for exacerbations in mild COPD. One randomised placebo-controlled study of 310 patients with mild-to-moderate COPD found that treatment of exacerbations with amoxicillin/ clavulanate was more effective than placebo and significantly prolonged the time to the next exacerbation compared with placebo [82].

The rate of $\mathrm{FEV}_{1}$ decline is increased in patients with mild COPD compared with controls without COPD and 
Table 3 Studies reporting pharmacological treatment efficacy in patients with mild COPD ${ }^{a}$

\begin{tabular}{|c|c|c|c|}
\hline Study & Population & Intervention & Finding \\
\hline \multicolumn{4}{|l|}{ Symptom burden } \\
\hline Kanner et al. 1999 [67] & $\begin{array}{l}\mathrm{COPD}\left(\mathrm{FEV}_{1} / \mathrm{FVC}<0.7 \text { and } \mathrm{FEV}_{1}\right. \\
55-90 \% \text { predicted })\end{array}$ & $\begin{array}{l}\text { Smoking cessation intervention with } \\
\text { SAMA (ipratropium bromide) or } \\
\text { placebo, versus usual care }\end{array}$ & $\begin{array}{l}\text { Lower prevalence of symptoms (no } \\
\text { additional effect of SAMA). Presence } \\
\text { of symptoms associated with greater } \\
\mathrm{FEV}_{1} \text { decline }\end{array}$ \\
\hline \multicolumn{4}{|l|}{ Exacerbations } \\
\hline Gartlehner et al. 2006 [68] & COPD, including mild COPD & $\begin{array}{l}\text { ICS (budesonide, fluticasone, } \\
\text { triamcinolone) versus placebo }\end{array}$ & $\begin{array}{l}\text { Reduced exacerbation rate. } \\
\text { Sub-analysis of } 3 \text { RCTs on mild COPD } \\
\text { found no effect }(n=191)\end{array}$ \\
\hline Jones et al. 2003 [69] & COPD, stratified by severity & ICS (fluticasone propionate) & $\begin{array}{l}\text { Reduced exacerbation rate in } \\
\text { moderate/severe, but not mild COPD }\end{array}$ \\
\hline \multicolumn{4}{|c|}{ Physical activity and exercise tolerance } \\
\hline Hirai et al. 2017 [70] & $\begin{array}{l}\text { Mild COPD (post-bronchodilator } \\
\mathrm{FEV}_{1} / \mathrm{FVC}<5 \text { th percentile LLN and } \\
\mathrm{FEV}_{1} \geq \mathrm{LLN} \text { ) }\end{array}$ & $\begin{array}{l}\text { Oral antioxidant (N-acetylcysteine) } \\
\text { versus placebo }\end{array}$ & $\begin{array}{l}\text { No effect on } \mathrm{O}_{2} \text { transport or exercise } \\
\text { tolerance }\end{array}$ \\
\hline Gagnon et al. 2012 [71] & Mild COPD & $\begin{array}{l}\text { SAMA/SABA (ipratropium bromide/ } \\
\text { salbutamol sulphate) }\end{array}$ & $\begin{array}{l}\text { Improved } \mathrm{FEV}_{1} \text { and hyperinflation; } \\
\text { no significant increase in walking } \\
\text { time }\end{array}$ \\
\hline \multicolumn{4}{|l|}{ Lung function decline } \\
\hline Zhou et al. 2017 [72] & Mild or moderate COPD & $\begin{array}{l}\text { LAMA (tiotropium bromide) versus } \\
\text { placebo }\end{array}$ & $\begin{array}{l}\text { Improvement in pre- and post-dose } \\
\mathrm{FEV}_{1} \text {; bronchodilator, reduced annual } \\
\text { decline in post-dose } \mathrm{FEV}_{1}\end{array}$ \\
\hline Wise et al. 2003 [73] & $\begin{array}{l}\text { Smokers with mild COPD }\left(\mathrm{FEV}_{1} / \mathrm{FVC}\right. \\
<0.7 \text { and } \mathrm{FEV}_{1} 50-90 \% \text { predicted) }\end{array}$ & $\begin{array}{l}\text { SAMA (ipratropium bromide) versus } \\
\text { placebo, both with smoking } \\
\text { cessation intervention (plus a usual } \\
\text { care control group) }\end{array}$ & $\begin{array}{l}\text { No effect on airway responsiveness } \\
\text { compared with placebo or usual } \\
\text { care }\end{array}$ \\
\hline Pauwels et al. 1999 [74] & $\begin{array}{l}\text { COPD (pre-bronchodilator } \mathrm{FEV}_{1} / \mathrm{FVC} \\
<0.7 \text { and post-bronchodilator } \mathrm{FEV}_{1} \\
50-100 \% \text { predicted) }\end{array}$ & ICS (budesonide) versus placebo & $\begin{array}{l}\text { Improvement in } \mathrm{FEV}_{1} \text { decline after } 6 \\
\text { months, but similar rate to placebo } \\
\text { from } 9 \text { months to end of study } \\
\text { ( } 36 \text { months) }\end{array}$ \\
\hline
\end{tabular}

COPD, chronic obstructive pulmonary disease; $\mathrm{FEV}_{1}$, forced expiratory volume in $1 \mathrm{~s}$; FVC, forced vital capacity; ICS, inhaled corticosteroid; LAMA, long-acting muscarinic antagonist; LLN, lower limit of normal; RCT: randomised controlled trial; SABA: short-acting $\beta_{2}$-agonist; SAMA: short-acting muscarinic antagonist. ${ }^{a}$ mild COPD defined as GOLD 0 and/or 1 COPD, unless otherwise stated

GOLD stages 2-4 [29]. Targeted pharmacological intervention in mild COPD could focus on specific patient subgroups, namely those with: (1) high symptom burden; (2) evidence of exacerbations; and (3) evidence of $\mathrm{FEV}_{1}$ decline. A long-acting bronchodilator should be the first-line treatment, as there is supporting evidence that these medicines can address symptoms, exacerbations and disease progression in patients with moderate COPD [72, 83-85], although we accept that direct evidence in mild COPD is lacking. Nevertheless, the advantage of the targeted approach proposed is to more intensively treat patients who are in greater need of symptomatic relief or who are at greater risk of disease progression.

\section{Challenges in implementing pharmacological intervention in mild COPD}

Current pharmacological treatment recommendations, such as those of GOLD, are not based on lung function, but focus instead on the categorisation of patients according to symptoms and history of exacerbations [1].
While there is clearly a logical rationale to this approach, the magnitude of effects of pharmacological interventions may vary according to disease severity. The lack of evidence to support the use of common maintenance COPD treatments (namely long-acting muscarinic antagonists, long-acting $\beta_{2}$-agonists, ICS and their combinations) in mild COPD is a concern. The optimum pharmacological treatment pathways for such patients remain unclear; properly designed clinical trials in patients with mild COPD are needed before any robust recommendations regarding pharmacological management can be made.

The problem with the simplistic approach of focusing on patients with GOLD stage 1 is that there are considerable differences in $\mathrm{FEV}_{1}$ trajectory that exist between individuals $[4,5]$. Importantly, individuals who had impaired lung growth in early life, and thus begin their $\mathrm{FEV}_{1}$ decline from a lower starting point [4], may be classed as having mild COPD even though they may never progress to moderate or severe COPD. The focus on mild COPD could lead to unnecessary treatment 
(with the potential for adverse effects) for some individuals if intervention in mild COPD was adopted indiscriminately as a management strategy. Furthermore, there is the danger of prescribing inhaled treatments for symptoms that are caused by COPD comorbidities, such as cardiovascular disease.

Although longitudinal cohort studies have followed patient populations with COPD for over 20 years [4], to date no studies have comprehensively described the pathological mechanisms associated with more rapid disease progression. There is a need to improve our understanding of the disease mechanisms and inflammatory processes responsible for disease progression that could be targeted with pharmacological intervention. This includes susceptibility to bacterial infection, mucus hypersecretion and small airway remodelling [86]. Understanding the mechanisms responsible for small airways inflammation and remodelling that occurs before the clinical diagnosis of COPD may help to identify new targets for pharmacological intervention beyond those of commonly used bronchodilators and would provide an opportunity for earlier intervention; this has the potential to reduce airway remodelling earlier in the disease process and slow disease progression.

\section{Conclusions}

Existing literature demonstrates that many patients with mild COPD suffer a substantial disease burden. While this suggests that patients with mild COPD could benefit from treatment intervention, the evidence for treatment efficacy in these patients is limited due to their exclusion from many clinical trials. We propose a practical solution in this situation, to target pharmacological management towards patients with mild COPD with greater symptoms, the presence of exacerbations and/or evidence of disease progression.

There is currently much interest in the concept of early COPD. However, identifying patients with mild COPD remains a relatively straightforward process, and offers the opportunity to identify patients at high risk of disease progression. Clinical trials of established and novel treatments are needed in this subgroup.

\section{Additional file}

Additional file 1: Table S1. Description of data: Studies reporting nonpharmacological treatment efficacy in patients with mild COPD. (PDF 17 kb)

\section{Abbreviations}

6MWT: 6-min walk test; ARIC: Atherosclerosis Risk in Communities; BMI: Body mass index;" CAT: COPD assessment test; CHS: Cardiovascular Health Study; $\mathrm{Cl}$ : Confidence interval; COPD: Chronic obstructive pulmonary disease; $\mathrm{CT}$ : Computed tomography; ECRHS: European Community Respiratory Health Survey; FEV : Forced expiratory volume in $1 \mathrm{~s}$; FVC: Forced vital capacity; GOLD: Global Initiative for Chronic Obstructive Lung Disease;

HCRU: Healthcare resource utilisation; HLQ: Health and labour questionnaire;
HR: Hazard ratio; HRQoL: Health-related quality of life; ICS: Inhaled corticosteroid; IRR: Incidence rate ratiö: LABA: Long-acting $\beta_{2}$-agonist: LAMA: Long-acting muscarinic antagonist; LLN: Lower limit of normal; mMRC: Modified Medical Research Council dyspnea scale; RCT: Randomised controlled trial; SABA: Short-acting $\beta_{2}$-agonist;; SAMA: Short-acting muscarinic antagonist; SAPALDIA: Swiss Study on Air Pollution and Lung Diseases in Adults; SD: Standard deviation; SF-36: 36-item Short-Form Survey; SGRQ: St George's Respiratory Questionnaire

\section{Acknowledgements}

DS is supported by the National Institute for Health Research Manchester Biomedical Research Centre. Medical writing support, under the direction of the authors, was provided by Nina Divorty, PhD, and Richard Knight, PhD, of CMC Connect, a division of McCann Health Medical Communications Ltd., Glasgow, UK and was funded by AstraZeneca, Cambridge, UK in accordance with Good Publication Practice (GPP3) guidelines (Ann Intern Med 2015; 163: 461-464).

\section{Authors' contributions}

$D S, A D$, JD and EK all contributed to the conception, data analysis/ interpretation and revision of the manuscript for intellectual content, and provided final approval of the manuscript.

\section{Funding}

Medical writing support was funded by AstraZeneca; however, no further funding was required and AstraZeneca had no influence on the content.

\section{Availability of data and materials}

Data sharing is not applicable to this article as no datasets were generated or analysed during the current study.

Ethics approval and consent to participate Not applicable.

\section{Consent for publication}

Not applicable.

\section{Competing interests}

DS has received research, consulting and lecturing fees from AstraZeneca, Boehringer Ingelheim, Chiesi, Cipla, Genentech, GlaxoSmithKline, Glenmark, Menarini, Mundipharma, Novartis, Peptinnovate, Pfizer, Pulmatrix, Therevance, and Verona. AD has received research, consulting and lecturing fees from Boehringer Ingelheim (Canada), and Novartis Canada. JD has received research, consulting and lecturing fees from AstraZeneca, GSK, Mylan, Sunovion, and Theravance. EK has received research, consulting and lecturing fees from Amphastar, AstraZeneca, Boehringer Ingelheim, Crisor LLC Research, GlaxoSmithKline, Mylan, Novartis, Oriel, Pearl, Sunovion, Teva, and Theravance.

\section{Author details}

${ }^{1}$ University of Manchester, Medicines Evaluation Unit, Manchester University NHS Foundation Trust, Manchester M23 9QZ, UK. ${ }^{2}$ Department of Family and Community Medicine, University of Toronto, Toronto, Ontario, Canada. ${ }^{3}$ Division of Pulmonary Diseases \& Critical Care Medicine, University of North Carolina Pulmonary Critical Medicine, Chapel Hill, North Carolina, USA.

${ }^{4}$ Clinical Research Institute, Medford, Oregon, USA.

Received: 5 March 2019 Accepted: 24 June 2019

Published online: 08 July 2019

References

1. Singh D, Agusti A, Anzueto A, Barnes PJ, Bourbeau J, Celli BR, et al. Global strategy for the diagnosis, management, and prevention of chronic obstructive lung disease: the GOLD science committee report 2019. Eur Respir J. 2019:53.

2. Mapel DW, Dalal AA, Blanchette CM, Petersen H, Ferguson GT. Severity of COPD at initial spirometry-confirmed diagnosis: data from medical charts and administrative claims. Int J Chron Obstruct Pulmon Dis. 2011;6:573-81.

3. Price D, Freeman D, Cleland J, Kaplan A, Cerasoli F. Earlier diagnosis and earlier treatment of COPD in primary care. Prim Care Respir J. 2011;20:15-22. 
4. Lange P, Celli B, Agustí A, Boje Jensen G, Divo M, Faner R, et al. Lungfunction trajectories leading to chronic obstructive pulmonary disease. N Engl J Med. 2015;373:111-22.

5. Vestbo J, Edwards LD, Scanlon PD, Yates JC, Agusti A, Bakke P, et al. Changes in forced expiratory volume in 1 second over time in COPD. N Engl J Med. 2011;365:1184-92.

6. Casanova C, de Torres JP, guirre-Jaime A, Pinto-Plata V, Marin JM, Cordoba $E$, et al. The progression of chronic obstructive pulmonary disease is heterogeneous: the experience of the BODE cohort. Am J Respir Crit Care Med. 2011;184:1015-21.

7. Ferguson GT. Maintenance pharmacotherapy of mild and moderate COPD: what is the evidence? Respir Med. 2011;105:1268-74.

8. Welte T, Vogelmeier C, Papi A. COPD: early diagnosis and treatment to slow disease progression. Int J Clin Pract. 2015;69:336-49.

9. de Marco R, Accordini S, Cerveri I, Corsico A, Sunyer J, Neukirch F, et al. An international survey of chronic obstructive pulmonary disease in young adults according to GOLD stages. Thorax. 2004;59:120-5.

10. Buist AS, McBurnie MA, Vollmer WM, Gillespie S, Burney P, Mannino DM, et al. International variation in the prevalence of COPD (the BOLD study): a population-based prevalence study. Lancet. 2007;370:741-50.

11. Rossi A, Butorac-Petanjek B, Chilosi M, Cosio BG, Flezar M, Koulouris N, et al. Chronic obstructive pulmonary disease with mild airflow limitation: current knowledge and proposal for future research - a consensus document from six scientific societies. Int J Chron Obstruct Pulmon Dis. 2017;12:2593-610.

12. Woodruff PG, Barr RG, Bleecker E, Christenson SA, Couper D, Curtis JL, et al. Clinical significance of symptoms in smokers with preserved pulmonary function. N Engl J Med. 2016;374:1811-21.

13. O'Donnell DE, Gebke KB. Activity restriction in mild COPD: a challenging clinical problem. Int J Chron Obstruct Pulmon Dis. 2014;9:577-88.

14. Lofdahl CG, Postma DS, Pride NB, Boe J, Thoren A. Possible protection by inhaled budesonide against ischaemic cardiac events in mild COPD. Eur Respir J. 2007;29:1115-9.

15. O'Donnell DE, Laveneziana P, Ora J, Webb KA, Lam YM, Ofir D. Evaluation of acute bronchodilator reversibility in patients with symptoms of GOLD stage I COPD. Thorax. 2009;64:216-23.

16. Maltais F, Dennis N, Chan CK. Rationale for earlier treatment in COPD: a systematic review of published literature in mild-to-moderate COPD. COPD. 2013;10:79-103

17. Travers J, Marsh S, Caldwell B, Williams M, Aldington S, Weatherall M, et al. External validity of randomized controlled trials in COPD. Respir Med. 2007;101:1313-20.

18. Fletcher C, Peto R. The natural history of chronic airflow obstruction. Br Med J. 1977;1:1645-8.

19. Vestbo J, Lange P. Natural history of COPD: focusing on change in FEV1. Respirology. 2016;21:34-43.

20. Rennard SI, Drummond MB. Early chronic obstructive pulmonary disease: definition, assessment, and prevention. Lancet. 2015;385:1778-88.

21. Martinez FJ, Han MK, Allinson JP, Barr RG, Boucher RC, Calverley PMA, et al. At the root: defining and halting progression of early chronic obstructive pulmonary disease. Am J Respir Crit Care Med. 2018;197:1540-51.

22. RETHINC: REdefining THerapy In Early COPD for the Pulmonary Trials Cooperative (RETHINC). 2018. https://clinicaltrials.gov/ct2/show/ NCT02867761. Accessed 30 Jan 2019.

23. Miravitlles M, Worth H, Soler Cataluña JJ, Price D, De Benedetto F, Roche N, et al. Observational study to characterise 24-hour COPD symptoms and their relationship with patient-reported outcomes: results from the ASSESS study. Respir Res. 2014;15:122.

24. Miravitlles M, Ribera A. Understanding the impact of symptoms on the burden of COPD. Respir Res. 2017;18:67.

25. Monteagudo M, Rodríguez-Blanco T, Llagostera M, Valero C, Bayona X, Ferrer $M$, et al. Factors associated with changes in quality of life of COPD patients: a prospective study in primary care. Respir Med. 2013;107:1589-97.

26. Tan WC, Hague CJ, Leipsic J, Bourbeau J, Zheng L, Li PZ, et al. Findings on thoracic computed tomography scans and respiratory outcomes in persons with and without chronic obstructive pulmonary disease: a populationbased cohort study. PLoS One. 2016;11:e0166745.

27. de Sousa Sena R, Ahmed S, Tan WC, Li PZ, Labonte L, Aaron SD, et al. Work productivity loss in mild to moderate COPD: lessons learned from the CanCOLD study. Eur Respir J. 2017:50(3):1701154.
28. Vaz Fragoso CA, McAvay G, Van Ness PH, Casaburi R, Jensen RL, Macintyre $\mathrm{N}$, et al. Phenotype of spirometric impairment in an aging population. Am J Resp Crit Care Med. 2016;193:727-35.

29. Bridevaux PO, Gerbase MW, Probst-Hensch NM, Schindler C, Gaspoz JM, Rochat T. Long-term decline in lung function, utilisation of care and quality of life in modified GOLD stage 1 COPD. Thorax. 2008;63:768-74.

30. Dransfield MT, Kunisaki KM, Strand MJ, Anzueto A, Bhatt SP, Bowler RP, et al. Acute exacerbations and lung function loss in smokers with and without chronic obstructive pulmonary disease. Am J Respir Crit Care Med. 2017;195:324-30.

31. Lee JY, Chon GR, Rhee CK, Kim DK, Yoon HK, Lee JH, et al. Characteristics of patients with chronic obstructive pulmonary disease at the first visit to a pulmonary medical center in Korea: the KOrea COpd subgroup study Team cohort. J Korean Med Sci. 2016;31:553-60.

32. Garcia-Aymerich J, Serra Pons I, Mannino DM, Maas AK, Miller DP, Davis KJ. Lung function impairment, COPD hospitalisations and subsequent mortality. Thorax. 2011;66:585-90.

33. Minas M, Hatzoglou C, Karetsi E, Papaioannou Al, Tanou K, Tsaroucha R, et al. COPD prevalence and the differences between newly and previously diagnosed COPD patients in a spirometry program. Prim Care Respir J. 2010;19:363-70.

34. Broekhuizen BD, Sachs AP, Verheij TJ, Janssen KJ, Asma G, Lammers JW, et al. Accuracy of symptoms, signs, and C-reactive protein for early chronic obstructive pulmonary disease. Br J Gen Pract. 2012;62:e632-8.

35. Hoogendoorn M, Feenstra TL, Boland M, Briggs AH, Borg S, Jansson SA, et al. Prediction models for exacerbations in different COPD patient populations: comparing results of five large data sources. Int J Chron Obstruct Pulmon Dis. 2017;12:3183-94.

36. Hurst JR, Vestbo J, Anzueto A, Locantore N, Mullerova H, Tal-Singer R, et al. Susceptibility to exacerbation in chronic obstructive pulmonary disease. N Engl J Med. 2010;363:1128-38.

37. Watz H, Pitta F, Rochester CL, Garcia-Aymerich J, ZuWallack R, Troosters T, et al. An official European Respiratory Society statement on physical activity in COPD. Eur Respir J. 2014;44:1521-37.

38. Troosters T, Bourbeau J, Maltais F, Leidy N, Erzen D, De Sousa D, et al. Enhancing exercise tolerance and physical activity in COPD with combined pharmacological and non-pharmacological interventions: PHYSACTO randomised, placebo-controlled study design. BMJ Open. 2016;6:e010106.

39. Reardon JZ, Lareau SC, ZuWallack R. Functional status and quality of life in chronic obstructive pulmonary disease. Am J Med. 2006;119:32-7.

40. Waschki B, Kirsten AM, Holz O, Mueller KC, Schaper M, Sack AL, et al. Disease progression and changes in physical activity in patients with chronic obstructive pulmonary disease. Am J Respir Crit Care Med. 2015;192:295-306

41. Watz H, Waschki B, Meyer T, Magnussen H. Physical activity in patients with COPD. Eur Respir J. 2009;33:262-72.

42. Garcia-Aymerich J, Lange P, Benet M, Schnohr P, Antó JM. Regular physical activity reduces hospital admission and mortality in chronic obstructive pulmonary disease: a population based cohort study. Thorax. 2006;61:772-8.

43. Jones JH, Zelt JT, Hirai DM, Diniz CV, Zaza A, O'Donnell DE, et al. Emphysema on thoracic $C T$ and exercise ventilatory inefficiency in mild-tomoderate COPD. COPD. 2017;14:210-8.

44. Caram LM, Ferrari R, Bertani AL, Garcia T, Mesquita CB, Knaut $C$, et al. Smoking and early COPD as independent predictors of body composition, exercise capacity, and health status. PLoS One. 2016;11:e0164290.

45. Stanojevic S, Wade A, Stocks J, Hankinson J, Coates AL, Pan H, et al. Reference ranges for spirometry across all ages: a new approach. Am J Respir Crit Care Med. 2008;177:253-60.

46. Vaz Fragoso CA, Concato J, McAvay G, Yaggi HK, Van Ness PH, Gill TM. Staging the severity of chronic obstructive pulmonary disease in older persons based on spirometric z-scores. J Am Geriatr Soc. 2011:59:1847-54.

47. Elbehairy AF, Ciavaglia CE, Webb KA, Guenette JA, Jensen D, Mourad SM, et al. Pulmonary gas exchange abnormalities in mild chronic obstructive pulmonary disease. Implications for dyspnea and exercise intolerance. Am J Respir Crit Care Med. 2015;191:1384-94.

48. Neder JA, Arbex FF, Alencar MC, O'Donnell CD, Cory J, Webb KA, et al. Exercise ventilatory inefficiency in mild to end-stage COPD. Eur Respir J. 2015;45:377-87. 
49. Guenette JA, Chin RC, Cheng S, Dominelli PB, Raghavan N, Webb KA, et al. Mechanisms of exercise intolerance in global initiative for chronic obstructive lung disease grade 1 COPD. Eur Respir J. 2014;44:1177-87.

50. Chin RC, Guenette JA, Cheng S, Raghavan N, Amornputtisathaporn N, Cortes-Telles A, et al. Does the respiratory system limit exercise in mild chronic obstructive pulmonary disease? Am J Respir Crit Care Med. 2013;187:1315-23.

51. Diaz AA, Morales A, Diaz JC, Ramos C, Klaassen J, Saldias F, et al. CT and physiologic determinants of dyspnea and exercise capacity during the six-minute walk test in mild COPD. Respir Med. 2013;107:570-9.

52. Ofir D, Laveneziana P, Webb KA, Lam YM, O'Donnell DE. Mechanisms of dyspnea during cycle exercise in symptomatic patients with GOLD stage I chronic obstructive pulmonary disease. Am J Respir Crit Care Med. 2008;177:622-9.

53. Carter R, Nicotra B, Blevins W, Holiday D. Altered exercise gas exchange and cardiac function in patients with mild chronic obstructive pulmonary disease. Chest. 1993;103:745-50.

54. Rossi A, Aisanov Z, Avdeev S, Di Maria G, Donner CF, Izquierdo JL, et al. Mechanisms, assessment and therapeutic implications of lung hyperinflation in COPD. Respir Med. 2015;109:785-802.

55. Castaldi PJ, Cho MH, Cohn M, Langerman F, Moran S, Tarragona N, et al. The COPD genetic association compendium: a comprehensive online database of COPD genetic associations. Hum Mol Genet. 2010;19:526-34.

56. Vogelmeier CF, Criner GJ, Martinez FJ, Anzueto A, Barnes PJ, Bourbeau J, et al. Global strategy for the diagnosis, management, and prevention of chronic obstructive lung disease 2017 report: GOLD executive summary. Eur Respir J. 2017:49:1700214.

57. Jenkins C, Jones PW, Calverley P, Celli B, Anderson JA, Ferguson GT, et al. Efficacy of salmeterol/fluticasone propionate by GOLD stage of chronic obstructive pulmonary disease: analysis from the randomised, placebocontrolled TORCH study. Respir Res. 2009;10:59.

58. Chen S, Wang C, Li B, Shi G, Li H, Zhang J, et al. Risk factors for FEV1 decline in mild COPD and high-risk populations. Int J Chron Obstruct Pulmon Dis. 2017;12:435-42.

59. Brito-Mutunayagam R, Appleton SL, Wilson DH, Ruffin RE, Adams RJ, North West Adelaide Cohort Health Study Team. Global initiative for chronic obstructive lung disease stage 0 is associated with excess FEV(1) decline in a representative population sample. Chest. 2010;138:605-13.

60. Mohamed Hoesein FAA, Zanen P, Boezen HM, Groen HJM, van Ginneken B, de Jong PA, et al. Lung function decline in male heavy smokers relates to baseline airflow obstruction severity. Chest. 2012;142:1530-8.

61. Stavem K, Sandvik L, Erikssen J. Can global initiative for chronic obstructive lung disease stage 0 provide prognostic information on long-term mortality in men? Chest. 2006;130:318-25.

62. Mannino DM, Buist AS, Petty TL, Enright PL, Redd SC. Lung function and mortality in the United States: data from the first National Health and nutrition examination survey follow up study. Thorax. 2003;58:388-93.

63. Putcha N, Drummond MB, Connett JE, Scanlon PD, Tashkin DP, Hansel NN, et al. Chronic productive cough is associated with death in smokers with early COPD. COPD. 2014;11:451-8.

64. Bale G, Martinez-Camblor P, Burge PS, Soriano JB. Long-term mortality follow-up of the ISOLDE participants: causes of death during 13 years after trial completion. Respir Med. 2008;102:1468-72.

65. Berry CE, Wise RA. Mortality in COPD: causes, risk factors, and prevention. COPD. 2010;7:375-82.

66. Tan WC, Bourbeau J, Hernandez P, Chapman KR, Cowie R, FitzGerald JM, et al. Exacerbation-like respiratory symptoms in individuals without chronic obstructive pulmonary disease: results from a population-based study. Thorax. 2014;69:709-17.

67. Kanner RE, Connett JE, Williams DE, Buist AS. Effects of randomized assignment to a smoking cessation intervention and changes in smoking habits on respiratory symptoms in smokers with early chronic obstructive pulmonary disease: the lung health study. Am J Med. 1999;106:410-6.

68. Gartlehner G, Hansen RA, Carson SS, Lohr KN. Efficacy and safety of inhaled corticosteroids in patients with COPD: a systematic review and metaanalysis of health outcomes. Ann Fam Med. 2006;4:253-62.

69. Jones PW, Willits LR, Burge PS, Calverley PM. Disease severity and the effect of fluticasone propionate on chronic obstructive pulmonary disease exacerbations. Eur Respir J. 2003;21:68-73.
70. Hirai DM, Jones JH, Zelt JT, da Silva ML, Bentley RF, Edgett BA, et al. Oral Nacetylcysteine and exercise tolerance in mild chronic obstructive pulmonary disease. J Appl Physiol. 2017;122:1351-61.

71. Gagnon P, Saey D, Provencher S, Milot J, Bourbeau J, Tan WC, et al. Walking exercise response to bronchodilation in mild COPD: a randomized trial. Respir Med. 2012;106:1695-705.

72. Zhou Y, Zhong NS, Li X, Chen S, Zheng J, Zhao D, et al. Tiotropium in earlystage chronic obstructive pulmonary disease. N Engl J Med. 2017:377:923-35.

73. Wise RA, Kanner RE, Lindgren P, Connett JE, Altose MD, Enright PL, et al. The effect of smoking intervention and an inhaled bronchodilator on airways reactivity in COPD: the lung health study. Chest. 2003;124:449-58.

74. Pauwels RA, Lofdahl CG, Laitinen LA, Schouten JP, Postma DS, Pride NB, et al. Long-term treatment with inhaled budesonide in persons with mild chronic obstructive pulmonary disease who continue smoking. European Respiratory Society study on chronic obstructive pulmonary disease. N Engl J Med. 1999;340:1948-53.

75. Troosters T, Sciurba FC, Decramer M, Siafakas NM, Klioze SS, Sutradhar SC, et al. Tiotropium in patients with moderate COPD naive to maintenance therapy: a randomised placebo-controlled trial. NPJ Prim Care Respir Med. 2014;24:14003.

76. McDonough JE, Yuan R, Suzuki M, Seyednejad N, Elliott WM, Sanchez PG, et al. Small-airway obstruction and emphysema in chronic obstructive pulmonary disease. N Engl J Med. 2011;365:1567-75.

77. Koo HK, Vasilescu DM, Booth S, Hsieh A, Katsamenis OL, Fishbane N, et al. Small airways disease in mild and moderate chronic obstructive pulmonary disease: a cross-sectional study. Lancet Respir Med. 2018;6:591-602.

78. Bhatt SP, Soler X, Wang X, Murray S, Anzueto AR, Beaty TH, et al. Association between functional small airway disease and FEV1 decline in chronic obstructive pulmonary disease. Am J Respir Crit Care Med. 2016;194:178-84.

79. Regan EA, Lynch DA, Curran-Everett D, Curtis JL, Austin JH, Grenier PA, et al. Clinical and radiologic disease in smokers with normal spirometry. JAMA Intern Med. 2015;175:1539-49.

80. Halpin DM, Decramer M, Celli B, Kesten S, Liu D, Tashkin DP. Exacerbation frequency and course of COPD. Int J Chron Obstruct Pulmon Dis. 2012;7:653-61.

81. Kesimer M, Ford AA, Ceppe A, Radicioni G, Cao R, Davis CW, et al. Airway mucin concentration as a marker of chronic bronchitis. N Engl J Med. 2017;377:911-22.

82. Llor C, Moragas A, Hernandez S, Bayona C, Miravitlles M. Efficacy of antibiotic therapy for acute exacerbations of mild to moderate chronic obstructive pulmonary disease. Am J Respir Crit Care Med. 2012;186:716-23.

83. Decramer M, Celli B, Kesten S, Lystig T, Mehra S, Tashkin DP. Effect of tiotropium on outcomes in patients with moderate chronic obstructive pulmonary disease (UPLIFT): a prespecified subgroup analysis of a randomised controlled trial. Lancet. 2009;374:1171-8.

84. Vestbo J, Anderson JA, Brook RD, Calverley PM, Celli BR, Crim C, et al. Fluticasone furoate and vilanterol and survival in chronic obstructive pulmonary disease with heightened cardiovascular risk (SUMMIT): a doubleblind randomised controlled trial. Lancet. 2016;387:1817-26.

85. Tashkin DP, Celli BR, Decramer M, Lystig T, Liu D, Kesten S. Efficacy of tiotropium in COPD patients with FEV1 $\geq 60 \%$ participating in the UPLIFT ${ }^{\oplus}$ trial. COPD. 2012;9:289-96.

86. Higham A, Quinn AM, Cancado JED, Singh D. The pathology of small airways disease in COPD: historical aspects and future directions. Respir Res. 2019;20:49.

\section{Publisher's Note}

Springer Nature remains neutral with regard to jurisdictional claims in published maps and institutional affiliations. 